Article

\title{
The LEPR Gene Is Associated with Reproductive Seasonality Traits in Rasa Aragonesa Sheep
}

\author{
Kenza Lakhssassi ${ }^{1}$, Malena Serrano ${ }^{2}{ }^{\mathbb{D}}$, Belén Lahoz ${ }^{1}$, María Pilar Sarto ${ }^{1}$, \\ Laura Pilar Iguácel ${ }^{1}{ }^{\circledR}$, José Folch ${ }^{1}$, José Luis Alabart ${ }^{1}$ and Jorge Hugo Calvo ${ }^{1,3, *(1)}$ \\ 1 Centro de Investigación y Tecnología Agroalimentaria de Aragón, Instituto Agroalimentario de \\ Aragón (IA2), CITA-Zaragoza University, 50059 Zaragoza, Spain; klakhssassi@cita-aragon.es (K.L.); \\ blahozc@aragon.es (B.L.); mpsarto@aragon.es (M.P.S.); lpiguacel@cita-aragon.es (L.P.I.); \\ jfolch@cita-aragon.es (J.F.); jlalabart@aragon.es (J.L.A.) \\ 2 Departamento de Mejora Genética Animal INIA, 28040 Madrid, Spain; malena@inia.es \\ 3 ARAID, 50018 Zaragoza, Spain \\ * Correspondence: jhcalvo@cita-aragon.es; Tel.: +34-976-716-471
}

Received: 9 November 2020; Accepted: 18 December 2020; Published: 21 December 2020

check for updates

Simple Summary: Seasonality of reproduction is one of the limiting factor of sheep production, with the leptin receptor $(L E P R)$ gene associated with some reproductive traits in different species. Thereby, we searched for polymorphisms in the ovine LEPR gene and associated them with three reproductive seasonality traits: the total days of anoestrous (TDA) and the progesterone cycling months (P4CM), both based on blood progesterone level and related to seasonal ovarian function; and the oestrous cycling months (OCM) as an indicator of oestrous behaviour. Two non-synonymous and non-linked single nucleotide polymorphisms (SNPs) in the LEPR gene were involved in the OCM trait (rs403578195 and rs405459906). These findings show for the first time the involvement of LEPR gene in seasonality reproduction in sheep and will help to improve genetic selection programs by implementing the genotyping of reproducers, which might increase the productivity of meat sheep.

\begin{abstract}
The aim of this study was to characterize and identify causative polymorphisms in the leptin receptor ( $L E P R)$ gene responsible for the seasonal variation of reproductive traits in sheep. Three reproductive seasonality traits were studied: the total days of anoestrous (TDA), the progesterone cycling months (P4CM) and the oestrous cycling months (OCM). In total, 18 SNPs were detected in 33 ewes with extreme values for TDA and OCM. Six SNPs were non-synonymous substitutions and two of them were predicted in silico as deleterious: rs596133197 and rs403578195. These polymorphisms were then validated in 239 ewes. The SNP rs403578195, located in exon 8 and leading to a change of alanine to glycine (Ala284Gly) in the extracellular domain of the protein, was associated with the OCM trait, being the G allele associated with a decrease of 12 percent of the OCM trait. Haplotype analyses also suggested the involvement of other non-synonymous SNP located in exon 20 (rs405459906). This SNP also produces an amino acid change (Lys1069Glu) in the intracellular domain of the protein and segregates independently of rs403578195. These results confirm for the first time the role of the LEPR gene in sheep reproductive seasonality.
\end{abstract}

Keywords: leptin receptor; reproductive seasonality; Rasa Aragonesa; SNP; haplotype

\section{Introduction}

The seasonality of reproduction in sheep is a general phenomenon in breeds originating from temperate climates, such as those raised in the Mediterranean basin. Changes in the photoperiod at temperate latitudes provide the main external cue that controls the timing of out-of-season fertility [1]. 
In Rasa Aragonesa, an autochthonous Mediterranean sheep breed from northeastern Spain reared for meat purposes, the maximal reproductive activity is associated with short days, with the highest percentage of ewes exhibiting ovulatory activities from August to March. This reproductive seasonality induces major variation in lamb production and therefore in the market price, which suffers a decline in the price of lambs from late spring to early fall when the lamb supply is the highest. To improve the reproductive efficiency of sheep, some producers use hormonal treatments and lighting manipulation, alone or in combination, to induce ewes to lamb out of season. Both treatments efficiently induce oestrous but add expenses to producers [2]. However, the increasing demand for hormone-free products has led to the search for alternative methods, such as the introduction of rams to previously isolated anoestrous ewes to ensure the induction of ovulation and oestrous (ram effect), nutritional flushing or the use of genetic markers to select as reproducers those animals with alleles associated with an increase in out-of-season fertility. In the case of Rasa Aragonesa, Folch and Alabart [3] showed that approximately $25 \%$ of ewes have spontaneous ovulations in spring and can be naturally mated throughout the year if management conditions and nutrition are suitable. It was proven that this spring ovulatory activity is under genetic control with heritability and repeatability values of 0.20 and 0.30 , respectively [4]. Seasonality is a complex trait with a strong environmental influence, expressed only in ewes, and manifested relatively late throughout life, and only in some management systems [5]. In this context, genomic approaches have been used to detect genes or genome regions influencing the ability of ewes to lamb out of season [5-19]. Including the selection of genotypes less sensitive to reproductive seasonality in breeding programs would be an alternative to increase the profitability and efficiency of the ovine sector.

Leptin gene polymorphisms have drawn much attention from animal scientists for their possible roles in economically important productive and reproductive traits [20]. In fact, leptin is primarily known for its role in the regulation of whole-body energy balance by acting on the central nervous system and influencing fat deposition in animals through the control of appetite and energy expenditure [21]. Recent experimental evidence has shown that some SNPs in the leptin receptor (LEPR) gene are associated with reproductive traits [22,23]. The physiological effects of $L E P R$ on reproduction, including puberty, the oestrous cycle, pregnancy, lactation, and even the early stages of embryonic development, have been proven $[24,25]$. Numerous research studies have shown that leptin controls sexual maturity at the hypothalamus level [26-28]. Moreover, the occurrence and involvement of leptin in the hypothalamus with the release of gonadotropic hormone confirms its role in sexual maturity or reproduction [29]. Thus, leptin seems to be an important link between metabolic status and the neuroendocrine axis [30]. However, melatonin influences reproductive function via activation of receptor sites within the hypothalamic-pituitary-gonadal axis [31]. The melatonin receptor subtype $1 A(M T N R 1 A)$ is considered a key gene that mediates photoperiodic reproductive seasonality in sheep [5-8,12-19]. Furthermore, expression of LEPR was detected in the suprachiasmatic nucleus (SCN), the mammalian "biological clock", and the pineal gland of ruminant species [32], suggesting an interaction between photoperiod, melatonin, and leptin [1]. Although receptors for leptin and melatonin have not yet been colocalized, their presence has been demonstrated in similar hypothalamic regions in sheep [32-34].

Leptin and its receptor have been suggested as markers for enhancing productivity in livestock and are also potential candidates for marker-assisted selection [35]. In sheep, polymorphisms in LEPR have been associated with delayed onset of puberty and with decreased ovulation and lambing rates in prolific Davisdale sheep [36], but no studies have been performed concerning the LEPR gene and its involvement in seasonality reproduction in sheep. Therefore, this study aimed to identify polymorphisms in several regions of the LEPR gene in Rasa Aragonesa sheep and to test their association with reproductive seasonality traits. 


\section{Materials and Methods}

\subsection{Ethics Statement}

All experimental procedures were performed in accordance with the guidelines of the European Union (2003/65/CE) and Spanish regulations (RD 1201/2005, BOE 252/34367e91) for the use and care of animals in research. No hormonal treatments were applied to the ewes during the study.

\subsection{Animal Samples}

As described by Martinez-Royo et al. [11], phenotypic seasonality data were obtained from a Rasa Aragonesa sheep flock managed in an experimental farm ("Pardina de Ayés") owned by Oviaragón S.C.L. The experimental period lasted from January to August 2012. The experimental flock was composed of 239 ewes in two age groups: 155 mature (5.2-7.2 y, $5.5 \pm 0.5$; mean \pm SD) and 84 young (all $1.9 \mathrm{y}, 1.9 \pm 0.0$ ) at the beginning of the experiment. Every three weeks, individual live weight (LW) and body condition score (BCS) on a 1 to 5 scale [37] were assessed. The mean LW and BCS were similar in both age groups. The pooled overall means and standard deviations for the whole experimental period were $52.5 \pm 7.7 \mathrm{~kg}$ and $2.9 \pm 0.3$ for LW and BCS, respectively. Management of the ewes was described by Martinez-Royo et al. [11]; all ewes were handled in a single lot and subjected to the same management, nutrition and environmental conditions.

\subsection{Measurement of Reproductive Seasonality Traits}

Three reproductive seasonality traits were considered and described by Martinez-Royo et al. [11]. Briefly, the first one was the total days of anoestrous (TDA), based on weekly individual plasma progesterone levels. TDA was the sum of days in anoestrous, with anoestrous defined as those periods with three or more consecutive progesterone concentrations lower than $0.5 \mathrm{ng} / \mathrm{mL}$. Likewise, ewes were not considered for this study if they were not cycling in the preceding breeding season (based on three samples taken one week apart in October), with progesterone levels under the threshold in all samples taken in January and with more than 4 consecutive samples higher than or equal to the threshold (possible pathological ewes). The second reproductive seasonality trait was the progesterone cycling months (P4CM), defined for each ewe as the rate of cycling months based on progesterone determinations. When the progesterone level was higher than or equal to $0.5 \mathrm{ng} / \mathrm{mL}$ in at least one blood sample in that month, the ewe was considered cyclic in a particular month. Finally, the third trait considered was the oestrous cycling months (OCM), defined as the rate of months cycling based on daily oestrous records for each ewe. Eight vasectomised rams fitted with harnesses and marking crayons were mixed with the ewes, and daily oestrous detection was performed [38]. Thus, after natural mating, oestrous was recorded as a colour mark on the rump of the ewes.

\subsection{LEPR Gene Characterization}

Genomic DNA was extracted from blood samples using standard protocols. The ovine LEPR gene is located on the chromosome OAR1, covering approximately $99 \mathrm{~kb}$ with 20 exons (GenBank acc. number NC_019458). Twelve exons were chosen to characterize the LEPR gene. These exons were selected based on having non-synonymous polymorphisms in the Ensembl Variation database (https: //www.ensembl.org/info/genome/variation/index.html) on the Oar 3.1 version of the sheep genome. Primers were designed using Primer3 software version 0.4.0 (http://bioinfo.ut.ee/primer3-0.4.0/), and were designed in the intron regions around the targeted exon. The details of the oligonucleotide sequences, the annealing temperature and expected product size are summarized in Table 1 . Polymerase chain reactions (PCRs) were performed in a $25 \mu \mathrm{L}$ reaction including $25 \mathrm{ng}$ of genomic DNA, 5 pmol of each primer, $200 \mathrm{nM}$ dNTPs, $2.4 \mathrm{mM} \mathrm{MgCl}_{2}, 50 \mathrm{mM} \mathrm{KCl}, 10 \mathrm{mM}$ Tris-HCl, 0.1\% Triton X-100 and $1 \mathrm{U}$ Taq polymerase (Biotools, Madrid, Spain). The cycling conditions were as follows: an initial denaturation step of $94{ }^{\circ} \mathrm{C}$ for $3 \mathrm{~min}, 35$ cycles of $94{ }^{\circ} \mathrm{C}$ for $30 \mathrm{~s}$, annealing temperature for $30 \mathrm{~s}$, and $72{ }^{\circ} \mathrm{C}$ for $30 \mathrm{~s}$ except for fragments 5,6 and 11 , which were $45 \mathrm{~s}$, and a final extension step 
of $72{ }^{\circ} \mathrm{C}$ for $5 \mathrm{~min}$. Direct Sanger sequencing of the PCR products from the 12 exons of 33 ewes with extreme values for TDA (low TDA: 0 days, $n=15$; high TDA: $149.3 \pm 22.3$ days, $n=18$ ) and OCM (low OCM: $0.24 \pm 0.12, n=18$; high OCM: $0.88 \pm 0.09, n=15$ ) were used to search for polymorphisms in the experimental population. The PCR products from genomic DNA were purified using the FlavorPrep Gel/PCR purification mini kit (Flavorgen, Ibian, Zaragoza, Spain) according to the manufacturer's instructions. The PCR products were sequenced in both directions by STAB Vida (Caparica, Portugal) using an ABI 3730XL sequencer (Applied Biosystems, Foster City, CA, USA). The homology searches were performed using BLAST (National Centre for Biotechnology Information: https://blast.ncbi.nlm.nih.gov/Blast.cgi). For alignment of the sequences, CLUSTAL Omega (http: //www.ebi.ac.uk/Tools/msa/clustalo/) and BioEdit [39] software were used. For prediction of the possible impact of an amino acid substitution on the structure and function of a protein, Variant Effect Predictor software (VEP: http://www.ensembl.org/Ovisaries/Tools/VEP?db=core) and PolyPhen-2 (http://genetics.bwh.harvard.edu/pph2/) [40] were used. Locations of SNPs were identified based on the genome version of Ovis aries Oar_v3.1. The secondary structure of the protein was determined from the amino acid sequence using CFSSP software (http://www.biogem.org/tool/chou-fasman/) [41].

Table 1. Primer sequences, location, annealing temperatures and amplification fragment sizes.

\begin{tabular}{|c|c|c|c|c|}
\hline PCR & Primer Sequence $\left(5^{\prime}-3^{\prime}\right)^{1}$ & Site & ${ }^{2} \mathrm{AT}\left({ }^{\circ} \mathrm{C}\right)$ & Size (bp) \\
\hline 1 & $\begin{array}{l}\text { F: TTTTTCTGTGTCTTTTGAATGTCC } \\
\text { R: AAGTAACAACTAATGCTTGGAACA }\end{array}$ & Exon 4 & 57 & 397 \\
\hline 2 & $\begin{array}{l}\text { F: GCTCTTTAAGCTGGGTGTGC } \\
\text { R: TTCAGCCTGTTTGAATGACTG }\end{array}$ & Exon 6 & 55 & 386 \\
\hline 3 & $\begin{array}{l}\text { F: TGCTAAAAATTCATTTTGACTTCG } \\
\text { R: GGAGGGCATCTCACCTTTTC }\end{array}$ & Exon 7 & 55 & 293 \\
\hline 4 & $\begin{array}{l}\text { F: CTGTCGCCAGCTAACTCCTC } \\
\text { R: CCTCCTTTTGAGTTACCACCA }\end{array}$ & Exon 8 & 55 & 378 \\
\hline 5 & $\begin{array}{l}\text { F: TGCCTGGTGAATCCTTTTTA } \\
\text { R: TCTCACCATATCCACAGAAAAAT }\end{array}$ & Exons 9-10 & 53 & 700 \\
\hline 6 & $\begin{array}{l}\text { F: AGAGCTGGGAATTCAGAAATG } \\
\text { R: TCTTTTCAATCCCACTGCAA }\end{array}$ & Exon 11 & 53 & 496 \\
\hline 7 & $\begin{array}{l}\text { F: CTGCTTGGCAGGTGGATT } \\
\text { R: CAGGAGGATGTATTTTATGCCAGT }\end{array}$ & Exon 12 & 55 & 392 \\
\hline 8 & $\begin{array}{l}\text { F: TGCCTACCAATGGGAAATGT } \\
\text { R: ATGGGAGGGGTTTGAAAGAT }\end{array}$ & Exon 15 & 55 & 383 \\
\hline 9 & $\begin{array}{l}\text { F: CCTGCTTTCTCTTCCTTCTTCC } \\
\text { R: TTTTTGAAGTTTTCATTAACTGTGTT }\end{array}$ & Exon 16 & 55 & 389 \\
\hline 10 & $\begin{array}{l}\text { F: CCAGTTTCAATCCATAAATCATCA } \\
\text { R: TGGCAGCATTGTTGCTAACT }\end{array}$ & Exon 17 & 55 & 299 \\
\hline 11 & $\begin{array}{l}\text { F: TGAAGCAAAACAAAACAAAACA } \\
\text { R: ACTCTCCTAACCAATGGTGAAA }\end{array}$ & Exon 20 & 52 & 974 \\
\hline
\end{tabular}

\subsection{LEPR Polymorphism Genotyping}

Genomic DNA was extracted from blood samples of 239 ewes from the total ewes of the flock using standard protocols. Six non-synonymous SNPs were selected for genotyping the whole population: one in exon 4 (rs411478947), exon 7 (rs596133197), and exon 8 (rs403578195) and three in exon 20 (rs412929474, rs428867159, and rs405459906) (Table 2). Only non-synonymous SNPs were selected because they produce changes in the translated amino acid residue sequence and are more likely to affect the structure and function of the encoded protein and so may influence the phenotype of interest. These SNPs were genotyped by Kompetitive Allele-Specific PCR (KASP) following the manufacturer's instructions. Sequences flanking SNPs for the SNPs were submitted for assay design to the genotyping platform provider (LGC Genomics, Biotools, Spain). For all samples, the KASP assay was carried out in a $10 \mu \mathrm{L}$ volume containing $20 \mathrm{ng}$ of genomic DNA, $5 \mu \mathrm{L}$ of KASP V4.0 2x Master mix standard 
ROX (LCG Genomics, Beverly, MA, USA) and 0.14 $\mu$ L of KASP-by-Design assay mix (LGC Genomics). Reactions were carried out in a CFX96 Bio-Rad thermocycler (Bio-Rad, Madrid, Spain) under the following conditions: $15 \mathrm{~min}$ at $94{ }^{\circ} \mathrm{C}$ followed by 9 cycles of $94{ }^{\circ} \mathrm{C}$ for $20 \mathrm{~s}$ and $57{ }^{\circ} \mathrm{C}$ for $1 \mathrm{~min}$ (dropping $-0.6{ }^{\circ} \mathrm{C}$ per cycle to achieve a $55^{\circ} \mathrm{C}$ annealing temperature), followed by 25 cycles of $94{ }^{\circ} \mathrm{C}$ for $20 \mathrm{~s}$ and $55^{\circ} \mathrm{C}$ for $1 \mathrm{~min}$. Following PCR, fluorescence was detected using a single quantification cycle for $1 \mathrm{~s}$ after cooling at $30^{\circ} \mathrm{C}$ for $2 \mathrm{~min}$.

\subsection{Statistical Analysis}

\subsubsection{SNP Association Studies}

The Hardy-Weinberg equilibrium exact test was applied and the observed and expected heterozygosities and the minor allele frequency (MAF) for each SNP were calculated using Haploview software v4.2 [42]. Statistical analyses were carried out as a regression of the phenotype values of the three reproductive seasonality traits on the SNP genotypes by fitting a linear model using the Rcmdr package of R software (http://socserv.socsci.mcmaster.ca/jfox/Misc/Rcmdr/) [43]. The model included the genotype of the SNPs (S), the age (mature and young) (A), and the interaction of age by genotype of the SNPs $(\mathrm{A} \times \mathrm{S})$ as fixed effects and the live weight $(\mathrm{LW})$ and body condition score $(\mathrm{BCS})$ as covariates. To test differences between genotypes, we estimated the least square means (LSMs) for each pairwise comparison for the SNP and SNP $x$ age effects. A Bonferroni correction was fitted to take into account multiple tests. All SNPs were independently analysed with the same statistical model.

\subsubsection{Haplotype Association Studies}

Blocks of linkage disequilibrium (LD) were evaluated with Haploview software v4.2 using the 4-gamete rule [42]. $\mathrm{D}^{\prime}$ and $\mathrm{r}^{2}$ within the LEPR were calculated and visualized in Figure 1. SNPs were phased with PLINK1.9 [44] using the expectation-maximization (E-M) algorithm to assign individual haplotypes. We considered diplotypes with a posterior probability higher than 0.7. Associations between the haplotypes and reproductive seasonality traits were performed by fitting a linear model using the Rcmdr package of R software. The model fit was similar to that used for the SNP association studies but included the haplotype $(\mathrm{H})$ effect and the interaction of age by haplotype $(\mathrm{A} \times \mathrm{H})$. Haplotypes for each individual were codified as 0,1 or 2, indicating the number of copies of each haplotype. Only haplotypes with a frequency greater than or equal to $1 \%$ were considered. To test differences between haplotypes, we estimated the LSMs for each pairwise comparison. The Bonferroni correction was applied to take into account multiple tests. 
Table 2. Information about the location and amino acid substitution effect of the identified SNPs according to the Variant Effect Predictor and PolyPhen-2 software in the LEPR gene. Scores for these programs are indicated in brackets. The SNPs are ordered according to their positions in the Oar3.1 genome version (Oar3.1: GenBank acc. number NC_019458). The amino acid positions are ordered according to their positions in GenBank acc. number ENSOARP00000011154 sequence.

\begin{tabular}{|c|c|c|c|c|c|c|c|}
\hline SNP & Alias $^{1}$ & Location & $\begin{array}{c}\text { Position in } \\
\text { OAR Version } 3.1\end{array}$ & $\begin{array}{l}\text { Nucleotide } \\
\text { Change }\end{array}$ & $\begin{array}{l}\text { Amino Acid } \\
\text { Change }\end{array}$ & $\begin{array}{c}\text { VEP } \\
\text { (SIFT Score) }\end{array}$ & PolyPhen-2 (Score) \\
\hline rs411478947 & snp_ex4 & Exon 4 & Oar1: g.40787726 & $\mathrm{C}>\mathrm{T}$ & Arg62Cys & Tolerated (0.05) & $\begin{array}{l}\text { Possibly damaging } \\
\qquad(0.74)\end{array}$ \\
\hline rs159694506 & & & Oar1: g.40787782 & $\mathrm{T}>\mathrm{C}$ & Asn $80=2$ & - & - \\
\hline rs159694508 & & & Oar1: g.40787821 & $\mathrm{T}>\mathrm{C}$ & Ser93 = & - & - \\
\hline rs596133197 & snp_ex7 & Exon 7 & Oar1: g.40813963 & $\mathrm{C}>\mathrm{T}$ & Thr248Ile & Deleterious (0) & $\begin{array}{c}\text { Probably damaging } \\
(0.98)\end{array}$ \\
\hline rs403578195 & snp_ex8 & Exon 8 & Oar1: g.40818703 & $C>G$ & Ala284Gly & Deleterious (0) & $\begin{array}{c}\text { Possibly damaging } \\
(0.77)\end{array}$ \\
\hline rs416296450 & & Intron 9 & Oar1: g.40825576 & $G>A$ & - & - & - \\
\hline rs404892216 & & Intron 10 & Oar1: g.40828606 & $A>G$ & - & - & - \\
\hline rs407234698 & & Exon 12 & Oar1: g.40833201 & $A>G$ & Pro561 = & - & - \\
\hline rs421946862 & & Exon 16 & Oar1: g.40840634 & $\mathrm{C}>\mathrm{T}$ & Ser791 = & - & - \\
\hline rs401262081 & & Intron 16 & Oar1: g.40840703 & $\mathrm{C}>\mathrm{T}$ & - & - & - \\
\hline rs403654953 & & Exon 20 & Oar1: g.40857538 & $\mathrm{C}>\mathrm{T}$ & Gly908 = & - & - \\
\hline rs412929474 & snp_ex20_1 & & Oar1: g.40857581 & $G>A$ & Val923Ile & Tolerated (0.5) & Benign (0.04) \\
\hline rs426037269 & & & Oar1: g.40857583 & $\mathrm{C}>\mathrm{T}$ & Val923 = & - & - \\
\hline rs415715948 & & & Oar1: g.40857634 & $\mathrm{C}>\mathrm{T}$ & Ala940 = & - & - \\
\hline rs428867159 & snp_ex20_2 & & Oar1: g.40857869 & $\mathrm{C}>\mathrm{T}$ & Pro1019Ser & Tolerated (0.77) & Benign (0.06) \\
\hline rs405459906 & snp_ex20_3 & & Oar1: g.40858019 & $A>G$ & Lys1069Glu & Tolerated (1) & Benign (0) \\
\hline rs414501727 & & & Oar1: g.40858045 & $\mathrm{C}>\mathrm{T}$ & Val1077 = & - & - \\
\hline rs427778198 & & & Oar1: g.40858219 & $\mathrm{G}>\mathrm{A}$ & $\mathrm{G} \ln 1135=$ & - & - \\
\hline
\end{tabular}

${ }^{1}$ Nomenclature used for each SNP in this work. ${ }^{2}$ No amino acid change. 


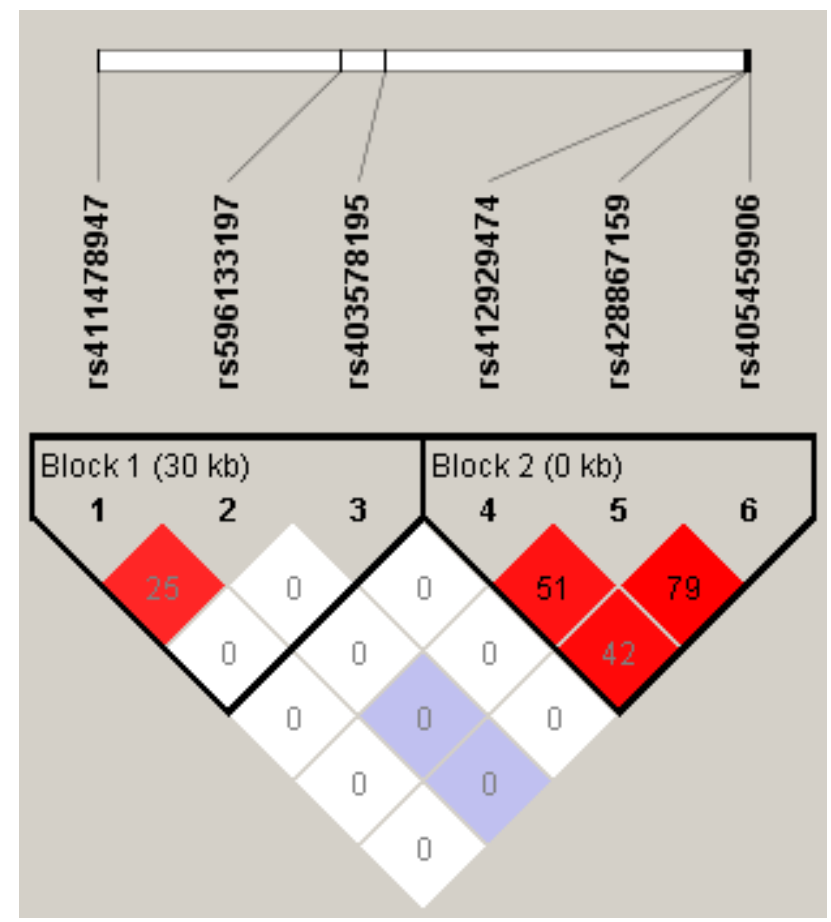

Figure 1. Linkage disequilibrium plot among the six non-conservative SNPs in LEPR using Haploview. The linkage disequilibrium colour scheme and values correspond with the $\mathrm{D}^{\prime}$ and $\mathrm{r}^{2}$ parameters, respectively. Strong $\mathrm{LD}\left(\mathrm{D}^{\prime}=1, \mathrm{LOD} \geq 2\right)$ is indicated in red. Red indicates varying degrees of $\mathrm{LD}$ with lighter shades displaying less than darker shades $\left(\mathrm{D}^{\prime}<1, \mathrm{LOD} \geq 2\right)$, and white indicates low $\mathrm{LD}$ $\left(\mathrm{D}^{\prime}<1, \mathrm{LOD}<2\right)$.

\section{Results}

\subsection{Isolation of the Partial Ovine LEPR Gene and Polymorphism Genotyping and Linkage Disequilibrium (LD)}

To identify polymorphisms in the LEPR gene, we sequenced twelve exons that have non-synonymous polymorphisms in the Ensembl Variation database (Table 1) (https://www.ensembl. org/info/genome/variation/index.html). These exons were located at the beginning, middle and end regions of the gene. In total, 18 SNPs were detected: 3 and 8 SNPs in exons 4 (rs411478947, rs159694506 and rs159694508) and 20 (rs412929474, rs428867159, rs405459906, rs403654953, rs426037269, rs415715948, rs414501727 and rs427778198), respectively, and 1 SNP in exons 7 (rs596133197), 8 (rs403578195), 12 (rs407234698) and 16 (rs421946862) and in introns 9 (rs416296450), 10 (rs404892216) and 16 (rs401262081) (Table 2). Six of these SNPs were non-synonymous substitutions and were genotyped in the whole population, with 2 (snp_ex7 and snp_ex8) and 3 (snp_ex4, snp_ex7 and snp_ex8) of them predicted as deleterious or possibly/probably damaging by VEP or PolyPhen-2 software, respectively (Table 2). These SNPs showed low MAFs, ranging between 0.023 (snp_ex7) and 0.065 (snp_ex4) (Supplementary Table S1).

To determine the extent of LD among these markers, we estimated the parameters $\mathrm{D}^{\prime}$ and $\mathrm{r}^{2}$ between all pairwise combinations of the six non-synonymous SNPs. The results of the LD analysis are shown in Figure 1, in which two LD blocks were predicted. Block 1 is composed of SNPs located in the extracellular domain of the protein (snp_ex4, snp_ex7 and snp_ex8), and Block 2 is composed of three missense mutations located in the cytoplasmic domain of the receptor in exon 20.

\subsection{SNP Association Studies}

For the association analyses, we used 239 ewes from which thirty-five ewes ( 29 adults and 6 young ewes) did not present anoestrous during the experiment based on TDA trait (TDA $=0)$. Similarly, 
seventy-seven (60 adult and 17 young) and nine ( 7 adult and 2 young) ewes were cycling during all the experiments based on P4CM and OCM traits, respectively. All SNPs were in Hardy-Weinberg equilibrium. Only snp_ex8 showed a significant association with OCM (CC vs. GC genotypes, $p=0.0027)$. Ewes with the CC genotype showed more oestrous records $(+0.12)$ than heterozygous ewes (Table 3). Details of type III test and LSMs for the SNP and the SNP x A effects for each SNP are provided in Supplementary Table S2. For the interaction effect between SNP and age, only the TDA phenotype differed among genotypes $(p<0.05)$ in young ewes for snp_ex20_1 after the Bonferroni correction (see Supplementary Table S2 for further details). Significant difference was found between the GG genotype and AG genotype $(p=0.04)$. Indeed, young ewes with the GG genotype had higher TDA values than heterozygotes. No significant differences were detected between the AA $(n=2)$ and AG $(n=14)$ genotypes in young ewes. It is worth noting that in our population, this SNP showed a low frequency for the A allele (0.10).

Table 3. Type III test for the significant SNPs and SNP by age (A) effects on the LEPR gene using the seasonal traits from Rasa Aragonesa ewes. The least square means (LSMs) and standard errors for the SNP and the SNP $x$ A effects on the LEPR gene are also shown. Only significant SNPs after Bonferroni correction are shown. Different letters indicate significant differences: ${ }^{\mathrm{a}, \mathrm{b}}: p<0.05$.

\begin{tabular}{|c|c|c|c|c|c|c|}
\hline \multirow{2}{*}{ SNP } & \multirow{2}{*}{ Trait } & \multirow{2}{*}{$p$ Value SNP } & \multirow{2}{*}{$\mathbf{A}$} & \multicolumn{3}{|c|}{ SNP LSMs } \\
\hline & & & & $\mathrm{CC}$ & GC & GG \\
\hline snp_ex8 & OCM & 0.003 & All & $0.54 \pm 0.01^{\mathrm{a}}$ & $0.42 \pm 0.03^{b}$ & - \\
\hline \multirow{2}{*}{ SNP } & \multirow{2}{*}{ Trait } & \multirow{2}{*}{$p$ Value $\mathrm{SNP} \times \mathbf{A}$} & \multirow{2}{*}{$\mathbf{A}$} & \multicolumn{3}{|c|}{ SNP $\times$ A LSMs } \\
\hline & & & & AA & AG & GG \\
\hline snp_ex20_1 & TDA & 0.0004 & Young & $80.6 \pm 31.09^{a, b}$ & $45.6 \pm 11.98^{a}$ & $83.3 \pm 6.41^{b}$ \\
\hline
\end{tabular}

\subsection{Haplotype Association Studies}

Haplotype association studies was performed taking into account the two LD blocks predicted with Haploview (Figure 1) and a block containing all SNPs (Block 0). In total, 17, 5 and 6 haplotypes were found for blocks 0, 1 and 2, respectively (Supplementary Table S3). We only considered diplotypes with a posterior probability higher than 0.7 and haplotype frequency $>0.01$. Thus, haplotype analysis was conducted considering 237/8, 237/4 and 235/4 ewes/haplotypes for blocks 0 (Supplementary Table S4), 1 (Supplementary Table S5) and 2 (Supplementary Table S6), respectively.

The significant association previously found between snp_ex20_1 by age and TDA phenotype was confirmed by haplotype association studies. In this sense, young ewes with no copies of the h1 (ATG) haplotype (in bold, snp_ex20_1) in block 2 had higher TDA values than those with 1 copy (Table 4). Moreover, in block 0, a significant effect was found for the h1 (GCCATG) haplotype containing allele A of the snp_ex20_1, showing that young ewes with one copy of $\mathrm{h} 1$ had more oestrous events than those without copies (Table 4).

Haplotypes $\mathrm{h} 2$ and $\mathrm{h} 8$ of block 0 were also associated with OCM considering the whole population. Ewes with 0 copies of the h2 (GCCGTG) or h8 (GCGATG) haplotypes (in bold, snp_ex8 and snp_ex20_3) showed more oestrous records than those with 1 copy. Notably, the h8 haplotype has the G allele (deleterious allele) of snp_ex8. Similarly, the analysis of block 1 showed that haplotype h1 (GCG), which also contains the G allele of snp_ex8, is associated with OCM. However, ewes with haplotype h2 for block 0 (GCCGTG) and block 2 (GTG) carry the G allele of snp_ex20_3, which was associated with less oestrous records (OCM), although this SNP did not show a significant $p$-value after Bonferroni correction in SNP association studies. 
Table 4. Type III test for the haplotype and haplotype by age (A) effects for blocks 0,1 and 2 on the LEPR gene using the seasonal phenotypic data from Rasa Aragonesa ewes. The least square means (LSMs) and standard errors for the haplotype effect on the LEPR gene are also shown. Only significant haplotypes after Bonferroni correction are shown. Different letters indicate significant differences: $\mathrm{a}, \mathrm{b}: p<0.05$.

\begin{tabular}{|c|c|c|c|c|c|c|c|c|}
\hline \multirow{2}{*}{$\begin{array}{l}\text { Haplotype } \\
\text { Block }^{1}\end{array}$} & \multirow{2}{*}{ Trait } & \multirow{2}{*}{ Haplotype } & \multirow{2}{*}{ Frequency } & \multirow{2}{*}{$\begin{array}{l}p \text { Value } \\
\text { Haplotype }\end{array}$} & \multirow{2}{*}{ A } & \multicolumn{3}{|c|}{ Haplotype LSMs ${ }^{2}$} \\
\hline & & & & & & 0 Copies & 1 Copy & 2 Copies \\
\hline \multirow[t]{2}{*}{ Block 0} & OCM & $\begin{array}{c}\text { h2 } \\
\text { (GCCGTG) }\end{array}$ & 0.07 & 0.002 & All & $\begin{array}{l}0.53 \pm \\
0.01^{\mathrm{a}}\end{array}$ & $\begin{array}{l}0.44 \pm \\
0.03\end{array}$ & - \\
\hline & OCM & $\begin{array}{c}\mathrm{h} 8 \\
\text { (GCGATG) }\end{array}$ & 0.01 & 0.004 & All & $\begin{array}{l}0.52 \pm \\
0.01^{\mathrm{a}}\end{array}$ & $\begin{array}{l}0.26 \pm \\
0.10^{b}\end{array}$ & - \\
\hline Block 1 & OCM & h1(GCG) & 0.05 & 0.003 & All & $\begin{array}{l}0.55 \pm \\
0.01^{\mathrm{a}}\end{array}$ & $\begin{array}{l}0.42 \pm \\
0.03 \mathrm{~b}\end{array}$ & - \\
\hline Block 2 & OCM & h2 (GTG) & 0.07 & 0.002 & All & $\begin{array}{l}0.54 \pm \\
0.01^{\mathrm{a}}\end{array}$ & $\begin{array}{l}0.44 \pm \\
0.033^{b}\end{array}$ & - \\
\hline \multirow{2}{*}{$\begin{array}{l}\text { Haplotype } \\
\text { Block }^{1}\end{array}$} & \multirow{2}{*}{ Trait } & \multirow{2}{*}{ Haplotype F } & \multirow{2}{*}{ Frequency } & \multirow{2}{*}{$\begin{array}{l}p \text { Value } \\
\text { Haplotype } \\
\times \mathrm{A}\end{array}$} & \multirow{2}{*}{ A } & \multicolumn{3}{|c|}{ Haplotype $\times$ A LSMs $^{2}$} \\
\hline & & & & & & 0 Copies & 1 Copy & 2 Copies \\
\hline Block 0 & OCM & h1(GCCATG) & ) 0.09 & 0.004 & Young & $\begin{array}{l}0.46 \pm \\
0.02^{a}\end{array}$ & $\begin{array}{l}0.66 \pm \\
0.05^{b}\end{array}$ & $\begin{array}{c}0.55 \pm \\
0.14^{\mathrm{a}, \mathrm{b}}\end{array}$ \\
\hline Block 2 & TDA & h1 (ATG) & 0.10 & 0.0003 & Young & $\begin{array}{l}83.9 \pm \\
6.38^{a}\end{array}$ & $\begin{array}{c}46.3 \pm \\
11.97^{b}\end{array}$ & $\begin{array}{c}81.4 \pm \\
31.09 \mathrm{a}, \mathrm{b}\end{array}$ \\
\hline
\end{tabular}

${ }^{1}$ Block 0: snp_ex4-snp_ex7-snp_ex8-snp_ex20_1-snp_ex20_2-snp_ex20_3; Block 1: snp_ex4-snp_ex7-snp_ex8; and Block2: snp_ex20_1-snp_ex20_2-snp_ex20_3. ${ }^{2} 0$ copy: LSMs and SE for 0 copies of the haplotype; 1 copy: LSMs and SE for 1 copy of the haplotype; and 2 copies: LSMs and SE for 2 copies of the haplotype.

\section{Discussion}

We detected 18 SNPs in the LEPR gene using 33 ewes with extreme values of TDA and OCM; six were non-synonymous substitutions, that were validated in 239 ewes. SIFT values varying from 0 to 1 were predicted for these SNPs by VEP software. SIFT scores lower than 0.05 suggest a potential intolerable amino acid substitution and a potential influence on protein function. In exon 4, a non-synonymous polymorphism (snp_ex4) promoting a change of arginine to cysteine at position 62 (according to their positions in GenBank acc. number ENSOARP00000011154) was detected, with this substitution predicted as tolerated but with a low SIFT value (0.05) and possibly damaging by VEP and PolyPhen-2 software, respectively (Table 2). Furthermore, arginine is a positively charged amino acid, whereas cysteine is polar in nature. This SNP was previously described by Haldar et al. [45] in Davisdale ewes. Of particular interest were two non-synonymous SNPs located in exons 7 and 8 and predicted as deleterious (SIFT $=0$ ) by VEP analysis. The first SNP in exon 7 (snp_ex7) produces an amino acid change from threonine (polar) to isoleucine (non-polar) at position 248, whereas the second SNP in exon 8 (snp_ex8) produces a change from alanine (non-polar) to glycine (non-polar) at position 284. These three SNPs found in exons 4, 7 and 8 are located in the extracellular domain of the protein, where different amino acid substitutions have been associated with obesity in humans [46]. The three SNPs found in exon 20 were located in the cytoplasmic domain of the receptor. Two of them (snp_ex20_2 and snp_ex20_3) were previously described by Haldar et al. [45]. None of the three non-synonymous substitutions found in exon 20 were predicted as deleterious, being considered tolerated or benign, with SIFT values ranging from 0.5 (snp_ex20_1) to 1 (snp_ex20_3).

We also studied whether these mutations alter the secondary structure of the protein. In fact, four of these mutations alter the predicted secondary structure of the mature protein. Snp_ex4 promotes a putative loss of two turns, which increases the length of the random coil structure in two amino acids. Snp_ex7 and snp_ex8 putatively change one alpha helix motif by a $\beta$-pleated sheet and a turn motif, respectively. Finally, snp_ex20_3 should promote a change of a random coil by an alpha helix motif. 
SNP association analysis showed that the non-conservative SNPs found in exons 4 and 7 were not associated with reproductive seasonality traits. These SNPs were predicted as tolerated (but with a low SIFT value) and deleterious, respectively, but they showed low MAF values ( 0.06 and 0.02 for snp_ex4 and snp_ex7, respectively) (Supplementary Table S1). Only one homozygous and no animals were found for the predicted tolerated and deleterious alleles (T alleles for both SNPs) of snp_ex4 and snp_ex7, respectively. However, Haldar et al. [45] found a strong association between snp_ex4 and puberty phenotypes $(p<0.001)$ but found a higher frequency for the T allele $(0.47)$. These researchers reported that ewe lambs homozygous for the T allele in the LEPR gene were less likely to attain puberty at 1 year of age than those that did not carry the mutation in Davisdale sheep. Therefore, statistically significant effects were found concerning OCM and the deleterious SNP mutation in exon 8, showing a low MAF (0.06) and no homozygous animals for the putative deleterious allele. Heterozygous animals for this SNP showed fewer oestrous records (OCM trait) than homozygous animals. As OCM indicates behavioural signs of oestrous, it could be inferred that natural selection against homozygous animals for the deleterious allele has led to a low frequency of this allele. Haplotype association analysis confirmed these results. In fact, ewes whose haplotype contains the $\mathrm{G}$ allele (deleterious mutation) for snp_ex8 showed less oestrous events.

The interaction between snp_ex20_1 and age affected TDA in young ewes. However, the opposite effect was found in adult ewes (Supplementary Table S2). This finding could indicate that this mutation is not responsible for the observed effect but could be in $\mathrm{LD}$ with some causative mutation. In this sense, snp_ex20_1 was in LD with snp_ex20_2 $\left(\mathrm{r}^{2}=0.51\right)$ and snp_ex20_3 $\left(\mathrm{r}^{2}=0.42\right)$ in the predicted haplotype block 2 (Figure 1). Moreover, ewes with haplotype h2 for block 0 (GCCGTG) and block 2 (GTG), carrying the G allele of snp_ex20_3, had significantly lower OCM values after Bonferroni correction, indicating the putative involvement of this SNP of the LEPR gene on the seasonal phenotypes. The SNPs at exon 20 segregate independently from those located in the extracellular domain, and different effects in two different regions of the LEPR protein were found in this study. One of them, snp_ex8, is located in the CRHI/immunoglobulin-like domain of the extracellular domain of the protein, where different amino acid substitutions have been associated with obesity and disrupted pubertal development in humans [46]. The second mutation, snp_ex20_3, was not associated with puberty traits in the work of Haldar et al. [45]. This mutation was not predicted as deleterious and was located in the cytoplasmic domain close to a conserved region (called box 3) around position 1079 in the amino acid sequence. In humans, multiple splice variants of $L E P R$ mRNA have been identified encoding an identical ligand binding domain but differing in the length of the cytosolic domain $[47,48]$. The LEPR isoforms A, B, $C$, and D have the same JAK binding motif encoded by exon 17 . However, only the LEPR-B isoform contains the Box 3 motif encoded by exon 20 for STAT activation $[47,49,50]$. This isoform is expressed ubiquitously and constitutes up to $35 \%$ of the LEPR transcripts in the hypothalamus [51]. Only the full-length LEPR isoform (LEPR-B isoform) is able to fully transduce an activating JAK/STAT signal into the cell. Remarkably, the intracellular domain of the B isoform contains three tyrosine residues (Y986, Y1079 and Y1141) that activate the intracellular STAT signal transduction pathway. Y1079 plays a dominant role in activating STAT5, and Y1141 activates STAT3 [46]. Then, snp_ex20_3 (Lys1069Glu) could modify the STAT5 binding motif and disrupt the JAK/STAT signalling pathway. However, in Y1138S LEPR-B mutant females in mice, this mutation induced impaired STAT3 signalling with residual STAT5 function, but it did not cause infertility [52]. In livestock species, Almeida et al. [53] investigated the SNP (T945M) polymorphism in exon 20 of the LEPR gene in Angus, Brangus and Charolais cattle and found no associations with reproductive characteristics. The authors reported that blood leptin levels were influenced by this LEPR SNP in late pregnancy but not during lactation. It is important to note that associations between a mutation and the observed phenotypes are not direct evidence that the mutations caused the observed changes in phenotype. The observed relationship could indicate that the SNP is in linkage disequilibrium with the true causative mutation [36]. In our study, we used a small sample size of ewes $(n=33)$ with extreme values for reproductive seasonality traits to look for polymorphisms that could be segregating in this population. This design could 
increase the power to detect polymorphic SNPs associated with the trait but minimized the probability of detecting other polymorphic SNPs. Furthermore, we did not sequence the complete coding region or regulatory regions, such as the promoter or $5^{\prime}$ and $3^{\prime}$ UTRs.

Although the relationships between individuals in the sample were unknown and then population stratification cannot be checked, the results with the SNP located in exon 8 are very consistent. This consistency is justified by the significant association with the OMC trait (in SNP and haplotype association analysis), the in silico prediction of the functional and structural consequences of this non-synonymous SNP (predicted as deleterious and affecting the secondary structure of the protein) and the location in the extracellular domain of the protein, where different amino acid substitutions have been associated with phenotype effects.

In summary, these results confirmed for the first time the involvement of the LEPR gene in reproductive seasonality. In this sense, several studies suggest that LEPR influences GnRH neuron activity and GnRH secretion by crosstalk with kisspeptin [54]. Kisspeptin cells are determinants of $\mathrm{GnRH} / \mathrm{LH}$ secretion in the different seasons and are responsible for activation of reproductive function. Clarke et al. [55] reported that kisspeptin expression in the arcuate nucleus is markedly reduced during the nonbreeding period and increased in ewes exposed to a short photoperiod and in the follicular phase of the cycle in the breeding season, suggesting the involvement of kisspeptin neurons in this activation. Kisspeptin neurons regulate GnRH neurons and transmit sex-steroid feedback to the reproductive axis (the trigger of increased LH secretion and gonadal activation), whereas a negative feedback of oestrogen on GnRH secretion is characteristic of the nonbreeding season [55]. This finding is comparable to that reported by other authors [56,57] about pubertal development events. In knockout mice and individuals with impaired LEPR function, disruption of pubertal development was found, as in the case of Davisdale ewes [45].

\section{Conclusions}

In conclusion, one SNP predicted as deleterious located in the extracellular domain of the LEPR gene (snp_ex8) was strongly associated with the oestrous cycling months in Rasa Aragonesa sheep, confirming for the first time the role of the LEPR gene in reproductive seasonality in ruminants. Furthermore, another non-linked SNP in exon 20 was associated with this trait, as shown in the haplotype association analysis. This SNP could be in linkage disequilibrium with other SNPs not detected in this study. The G alleles of snp_ex8 and snp_ex20_3 are associated with higher OCM values, which indicate behavioural signs of oestrous in the Rasa Aragonesa breed. Genetic selection programs can be enhanced by implementing the genotyping of reproducers for these alleles related to reproductive seasonality, which might increase the productivity of meat sheep. 
Supplementary Materials: The following are available online at http://www.mdpi.com/2076-2615/10/12/2448/s1, Table S1: Genotypic and allelic frequencies of the identified SNPs, Table S2: Type III test for the body condition (BC), live weight (LW), age (A), SNP, and SNP $\times$ age effects for the LEPR polymorphisms using the seasonality phenotype data from Rasa Aragonesa ewes. The least square means (LSMs) and standard errors of the LEPR polymorphisms in the seasonality phenotype data in Rasa Aragonesa ewes are also shown, Table S3: Haplotypes combination and frequency for block 0 (rs411478947-rs596133197-rs403578195-rs412929474-rs428867159-rs405459906), block 1 (rs411478947-rs596133197-rs403578195) and 2 (rs412929474-rs428867159-rs405459906). Only haplotypes with a frequency higher than $1 \%$ are shown, Table S4: Type III test for the body condition (BC), live weight (LW), age (A), haplotype $(\mathrm{H})$, and haplotype $\times$ age $(\mathrm{H} \times \mathrm{A})$ effects for the Block 0 haplotype using the seasonality phenotype data from Rasa Aragonesa ewes. The least square means (LSMs) and standard errors of the LEPR polymorphisms in the seasonality phenotype data in Rasa Aragonesa ewes are also shown, Table S5: Type III test for the body condition $(\mathrm{BC})$, live weight $(\mathrm{LW})$, age $(\mathrm{A})$, haplotype $(\mathrm{H})$, and haplotype $\times$ age $(\mathrm{H} \times \mathrm{A})$ effects for the Block 1 haplotype using the seasonality phenotype data from Rasa Aragonesa ewes. The least square means and standard errors of the LEPR polymorphisms in the seasonality phenotype data in Rasa Aragonesa ewes are also shown, Table S6: Type III test for the body condition (BC), live weight (LW), age (A), haplotype (H), and haplotype $\times$ age $(\mathrm{H} \times \mathrm{A})$ effects for the Block 2 haplotype using the seasonality phenotype data from Rasa Aragonesa ewes. The least square means and standard errors of the LEPR polymorphisms in the seasonality phenotype data in Rasa Aragonesa ewes are also shown.

Author Contributions: Conceptualization, M.S., J.L.A. and J.H.C.; methodology, M.S. and J.H.C.; formal analysis, K.L. and J.H.C.; investigation, K.L., M.P.S., and L.P.I.; data curation, K.L., M.S., J.L.A. and J.H.C.; writing-original draft preparation, K.L.; writing-review and editing K.L., M.S., B.L., J.F. and J.H.C.; supervision, M.S. and J.H.C.; project administration, J.H.C.; funding acquisition, J.L.A. and J.H.C. All authors have read and agreed to the published version of the manuscript.

Funding: This study was partially financed by the Ministry of Science, Innovation and Universities of Spain research project INIA-RTA2015-00090, the Research Group Funds of the Aragón Government (Grupo SAGAS Ref. A14_17R) and is co-financed by FEDER. K. Lakhssassi is supported by a doctoral grant from the Ministry of Science, Innovation and Universities of Spain (BES-2017-080154).

Acknowledgments: We would like to thank UPRA-Grupo Pastores for providing the experimental animals and facilities for the study.

Conflicts of Interest: The authors declare no conflict of interest.

\section{References}

1. Malpaux, B.; Robinson, J.E.; Wayne, N.L.; Karsch, F.J. Regulation of the onset of the breeding season of the ewe: Importance of long days and of an endogenous reproductive rhythm. J. Endocrinol. 1989, 122, 269-278. [CrossRef] [PubMed]

2. Posbergh, C.J.; Thonney, M.L.; Huson, H.J. Genomic Approaches Identify Novel Gene Associations with Out of Season Lambing in Sheep. J. Hered. 2019, 110, 577-586. [CrossRef] [PubMed]

3. Folch, J.; Alabart, J.L. Respuesta al efecto macho de ovejas rasa aragonesa según su estado cíclico tratadas o no con melatonina en primavera. ITEA 1999, 20, 651-653.

4. Hanocq, E.; Bodin, L.; Thimonier, J.; Teyssier, J.; Malpaux, B.; Chemineau, P. Genetic parameters of spontaneous spring ovulatory activity in Merinos d'Arles sheep. Genet. Sel. Evol. 1999, 31, 77-90. [CrossRef]

5. Notter, D.R.; Cockett, N.E.; Hadfield, T.S. Evaluation of melatonin receptor 1a as a candidate gene influencing reproduction in an autumn-lambing sheep flock. J. Anim. Sci. 2003, 81, 912-917. [CrossRef]

6. Pelletier, J.; Bodin, L.; Hanocq, E.; Malpaux, B.; Teyssier, J.; Thimonier, J.; Chemineau, P. Association Between Expression of Reproductive Seasonality and Alleles of the Gene for Mella Receptor in the Ewe. Biol. Reprod. 2000, 62, 1096-1101. [CrossRef]

7. Mura, M.C.; Luridiana, S.; Bodano, S.; Daga, C.; Cosso, G.; Diaz, M.L.; Bini, P.P.; Carcangiu, V. Influence of melatonin receptor $1 \mathrm{~A}$ gene polymorphisms on seasonal reproduction in Sarda ewes with different body condition scores and ages. Anim. Reprod. Sci. 2014, 149, 173-177. [CrossRef]

8. Calvo, J.H.; Serrano, M.; Martinez-Royo, A.; Lahoz, B.; Sarto, P.; Ibañez-Deler, A.; Folch, J.; Alabart, J.L. SNP rs403212791 in exon 2 of the MTNR1A gene is associated with reproductive seasonality in the Rasa aragonesa sheep breed. Theriogenology 2018, 113, 63-72. [CrossRef]

9. Bai, D.-p.; Yu, C.-j.; Chen, Y.-1. Association between AA-NAT gene polymorphism and reproductive performance in sheep. Electron. J. Biotechnol. 2012, 15, 86-92. [CrossRef]

10. Mateescu, R.G.; Thonney, M.L. Genetic mapping of quantitative trait loci for aseasonal reproduction in sheep. Anim. Genet. 2010, 41, 454-459. [CrossRef] 
11. Martinez-Royo, A.; Alabart, J.L.; Sarto, P.; Serrano, M.; Lahoz, B.; Folch, J.; Calvo, J.H. Genome-wide association studies for reproductive seasonality traits in Rasa Aragonesa sheep breed. Theriogenology 2017, 99, 21-29. [CrossRef] [PubMed]

12. Chu, M.X.; Ji, C.L.; Chen, G.H. Association between PCR-RFLP of melatonin receptor 1a gene and high prolificacy in Small Tail Han sheep. Asian Australas. J. Anim. Sci. 2003, 16, 1701-1704. [CrossRef]

13. Faigl, V.; Kerestes, M.; Kulcsar, M.; Reiczigel, J.; Cseh, S.; Huszenicza, G.; Arnyasi, M.; Javor, A. Seasonality of reproduction and MT1 receptor gene polymorphism in Awassi sheep. Reprod. Domest. Anim. 2009, 43, 11.

14. Mura, M.C.; Luridiana, S.; Vacca, G.M.; Bini, P.P.; Carcangiu, V. Effect of genotype at the MTNR1A locus and melatonin treatment on first conception in Sarda ewe lambs. Theriogenology 2010, 74, 1579-1586. [CrossRef]

15. Mateescu, R.G.; Lunsford, A.K.; Thonney, M.L. Association between melatonin receptor 1A gene polymorphism and reproductive performance in Dorset ewes. J. Anim. Sci. 2009, 87, 2485-2488. [CrossRef]

16. Teyssier, J.; Migaud, M.; Debus, N.; Maton, C.; Tillard, E.; Malpaux, B.; Chemineau, P.; Bodin, L. Expression of seasonality in Merinos d'Arles ewes of different genotypes at the MT1 melatonin receptor gene. Animal 2011, 5, 329-336. [CrossRef]

17. Carcangiu, V.; Mura, M.C.; Vacca, G.M.; Pazzola, M.; Dettori, M.L.; Luridiana, S.; Bini, P.P. Polymorphism of the melatonin receptor MT1 gene and its relationship with seasonal reproductive activity in the Sarda sheep breed. Anim. Reprod. Sci. 2009, 116, 65-72. [CrossRef]

18. Carcangiu, V.; Luridiana, S.; Vacca, G.M.; Daga, C.; Mura, M.C. A polymorphism at the melatonin receptor 1A (MTNR1A) gene in Sarda ewes affects fertility after AI in the spring. Reprod. Fertil. Dev. 2011, 23, 376-380. [CrossRef]

19. Martínez-Royo, A.; Lahoz, B.; Alabart, J.L.; Folch, J.; Calvo, J.H. Characterisation of the Melatonin Receptor 1A (MTNR1A) gene in the Rasa Aragonesa sheep breed: Association with reproductive seasonality. Anim. Reprod. Sci. 2012, 133, 169-175. [CrossRef]

20. van der Lende, T.; te Pas, M.F.W.; Veerkamp, R.F.; Liefers, S.C. Leptin Gene Polymorphisms and Their Phenotypic Associations. Vitam. Horm. 2005, 71, 373-404. [CrossRef]

21. Paczoska-Eliasiewicz, H.E.; Proszkowiec-Weglarz, M.; Proudman, J.; Jacek, T.; Mika, M.; Sechman, A.; Rzasa, J.; Gertler, A. Exogenous leptin advances puberty in domestic hen. Domest. Anim. Endocrinol. 2006, 31, 211-226. [CrossRef] [PubMed]

22. Liefers, S.C.; Veerkamp, R.F.; Te Pas, M.F.W.; Delavaud, C.; Chilliard, Y.; Van Der Lende, T. A missense mutation in the bovine leptin receptor gene is associated with leptin concentrations during late pregnancy. Anim. Genet. 2004, 35, 138-141. [CrossRef] [PubMed]

23. Israel, D.; Chua, S. Leptin receptor modulation of adiposity and fertility. Trends Endocrinol. Metab. 2010, 21, 10-16. [CrossRef] [PubMed]

24. Moschos, S.; Chan, J.L.; Mantzoros, C.S. Leptin and reproduction: A review. Science 2002, 77, 433-444. [CrossRef]

25. Taheri, S.J.; Parham, A. Sheep oocyte expresses leptin and functional leptin receptor mRNA. Asian Pac. J. Reprod. 2016, 5, 395-399. [CrossRef]

26. Ehrhardt, R.A.; Bell, A.W.; Boisclair, Y.R. Spatial and developmental regulation of leptin in fetal sheep. Am. J. Physiol. Regul. Integr. Comp. Physiol. 2002, 282. [CrossRef]

27. Agarwal, R.; Rout, P.K.; Singh, S.K. Leptin: A biomolecule for enhancing livestock productivity. Indian J. Biotechnol. 2009, 8, 169-176.

28. Saleem, A.; Hussain, T.; Tahir, M.; Ali, A.; Khan, W.; Dawood, M.; Ali, R.; Rehman, Z. Role of Leptin in Growth, Reproduction and Milk Production in Farm Animals: A Review. Adv. Anim. Vet. Sci. 2015, 3, 302-307. [CrossRef]

29. Zieba, D.A.; Amstalden, M.; Williams, G.L. Regulatory roles of leptin in reproduction and metabolism: A comparative review. Domest. Anim. Endocrinol. 2005, 29, 166-185. [CrossRef]

30. Barb, C.R.; Kraeling, R.R. Role of leptin in the regulation of gonadotropin secretion in farm animals. Anim. Reprod. Sci. 2004, 82-83, 155-167. [CrossRef]

31. Malpaux, B.; Migaud, M.; Tricoire, H.; Chemineau, P. Biology of mammalian photoperiodism and the critical role of the pineal gland and melatonin. J. Biol. Rhythms 2001, 16, 336-347. [CrossRef] [PubMed]

32. Chelikani, P.K.; Glimm, D.R.; Kennelly, J.J. Short communication: Tissue distribution of leptin and leptin receptor mRNA in the bovine. J. Dairy Sci. 2003, 86, 2369-2372. [CrossRef] 
33. Dyer, C.J.; Simmons, J.M.; Matteri, R.L.; Keisler, D.H. Leptin receptor mRNA is expressed in ewe anterior pituitary and adipose tissues and is differentially expressed in hypothalamic regions of well-fed and feed-restricted ewes. Domest. Anim. Endocrinol. 1997, 14, 119-128. [CrossRef]

34. Miller, D.W.; Findlay, P.A.; Morrison, M.A.; Raver, N.; Adam, C.L. Seasonal and dose-dependent effects of intracerebroventricular leptin on LH secretion and appetite in sheep. J. Endocrinol. 2002, 175, 395-404. [CrossRef]

35. De Matteis, G.; Scatà, M.C.; Catillo, G.; Terzano, G.M.; Grandoni, F.; Napolitano, F. Characterization of leptin receptor gene in Bubalus bubalis and association analysis with body measurement traits. Mol. Biol. Rep. 2015, 42, 1049-1057. [CrossRef]

36. Juengel, J.L.; French, M.C.; O'Connell, A.R.; Edwards, S.J.; Haldar, A.; Brauning, R.; Farquhar, P.A.; Dodds, K.G.; Galloway, S.M.; Johnstone, P.D.; et al. Mutations in the leptin receptor gene associated with delayed onset of puberty are also associated with decreased ovulation and lambing rates in prolific Davisdale sheep. Reprod. Fertil. Dev. 2016, 28, 1318. [CrossRef]

37. Russel, A.J.F.; Doney, J.M.; Gunn, R.G. Subjective assessment of body fat in live sheep. J. Agric. Sci. 1969, 72, 451-454. [CrossRef]

38. Radford, H.M.; Watson, R.H.; Wood, G.F. A crayon and associated harness for the detection op mating under field conditions. Aust. Vet. J. 1960, 36, 57-66. [CrossRef]

39. Hall, T.A.; Hall, T.A. Bioedit: A user-friendly biological sequence alignment editor and analysis program for windows 95/98/NT. In Nucleic Acids Symposium Series; Information Retrieval Ltd.: London, UK, 1999; pp. 95-98. [CrossRef]

40. Adzhubei, I.A.; Schmidt, S.; Peshkin, L.; Ramensky, V.E.; Gerasimova, A.; Bork, P.; Kondrashov, A.S.; Sunyaev, S.R. A method and server for predicting damaging missense mutations. Nat. Methods 2010, 7, 248-249. [CrossRef]

41. Kumar, T.A. CFSSP: Chou and Fasman Secondary Structure Prediction server. Wide Spectr. 2013, 1, 15-19.

42. Barrett, J.C.; Fry, B.; Maller, J.; Daly, M.J. Haploview: Analysis and visualization of LD and haplotype maps. Bioinformatics 2005, 21, 263-265. [CrossRef] [PubMed]

43. Fox, J.; Bouchet-Valat, M.; Andronic, L.; Ash, M.; Boye, T.; Calza, S.; Chang, A.; Grosjean, P.; Heiberger, R.; Pour, K.K.; et al. Package "Rcmdr". 2020. Available online: cran.ma.imperial.ac.uk/web/packages/Rcmdr/ Rcmdr.pdf (accessed on 26 October 2020).

44. Purcell, S.; Neale, B.; Todd-Brown, K.; Thomas, L.; Ferreira, M.A.R.; Bender, D.; Maller, J.; Sklar, P.; De Bakker, P.I.W.; Daly, M.J.; et al. PLINK: A Tool Set for Whole-Genome Association and Population-Based Linkage Analyses. Am. J. Hum. Genet. 2007, 81, 559-575. [CrossRef] [PubMed]

45. Haldar, A.; French, M.C.; Brauning, R.; Edwards, S.J.; O'connell, A.R.; Farquhar, P.A.; Davis, G.H.; Johnstone, P.D.; Juengel, J.L. Single-Nucleotide Polymorphisms in the LEPR Gene Are Associated with Divergent Phenotypes for Age at Onset of Puberty in Davisdale Ewes 1. Biol. Reprod. 2014, 90, 33-34. [CrossRef] [PubMed]

46. Nunziata, A.; Funcke, J.-B.; Borck, G.; von Schnurbein, J.; Brandt, S.; Lennerz, B.; Moepps, B.; Gierschik, P.; Fischer-Posovszky, P.; Wabitsch, M. Functional and Phenotypic Characteristics of Human Leptin Receptor Mutations. J. Endocr. Soc. 2019, 3, 27-41. [CrossRef] [PubMed]

47. Tartaglia, L.; Dembski, M.; Weng, X.; Deng, N.; Culpepper, J.; Devos, R.; Richards, G.; Campfield, L.; Clark, F.; Deeds, J.; et al. Identification and expression cloning of a leptin receptor, OB-R. Cell 1995, 83, 1263-1271. [CrossRef]

48. Lee, G.H.; Proenca, R.; Montez, J.M.; Carroll, K.M.; Darvishzadeh, J.G.; Lee, J.I.; Friedman, J.M. Abnormal splicing of the leptin receptor in diabetic mice. Nature 1996, 379, 632-635. [CrossRef] [PubMed]

49. Tartaglia, L.A. The leptin receptor. J. Biol. Chem. 1997, 272, 6093-6096. [CrossRef]

50. Chua, S.C.; Koutras, I.K.; Han, L.; Liu, S.M.; Kay, J.; Young, S.J.; Chung, W.K.; Leibel, R.L. Fine structure of the murine leptin receptor gene: Splice site suppression is required to form two alternatively spliced transcripts. Genomics 1997, 45, 264-270. [CrossRef]

51. Löllmann, B.; Grüninger, S.; Stricker-Krongrad, A.; Chiesi, M. Detection and Quantification of the Leptin Receptor Splice Variants Ob-Ra, b, and e in Different Mouse Tissues. Biochem. Biophys. Res. Commun. 1997, 241, 803. [CrossRef] 
52. Bates, S.H.; Stearns, W.H.; Dundon, T.A.; Schubert, M.; Tso, A.W.K.; Wang, Y.; Banks, A.S.; Lavery, H.J.; Haq, A.K.; Maratos-Flier, E.; et al. STAT3 signalling is required for leptin regulation of energy balance but not reproduction. Nature 2003, 421, 856-859. [CrossRef]

53. Almeida, S.E.M.; Santos, L.B.S.; Passos, D.T.; Corbellini, Â.O.; Lopes, B.M.T.; Kirst, C.; Terra, G.; Neves, J.P.; Gonçalves, P.B.D.; Moraes, J.C.F.; et al. Genetic polymorphisms at the leptin receptor gene in three beef cattle breeds. Genet. Mol. Biol. 2008, 31, 680-685. [CrossRef]

54. Elias, C.F. Leptin action in pubertal development: Recent advances and unanswered questions. Trends Endocrinol. Metab. 2012, 23, 9-15. [CrossRef] [PubMed]

55. Clarke, I.J.; Smith, J.T.; Caraty, A.; Goodman, R.L.; Lehman, M.N. Kisspeptin and seasonality in sheep. Peptides 2009, 30, 154-163. [CrossRef]

56. Lutz, T.A.; Woods, S.C. Overview of animal models of obesity. Curr. Protoc. Pharmacol. 2012, 58, 5-61. [CrossRef] [PubMed]

57. Von Schnurbein, J.; Moss, A.; Nagel, S.A.; Muehleder, H.; Debatin, K.M.; Farooqi, I.S.; Wabitsch, M. Leptin substitution results in the induction of menstrual cycles in an adolescent with leptin deficiency and hypogonadotropic hypogonadism. Horm. Res. Paediatr. 2012, 77, 127-133. [CrossRef] [PubMed]

Publisher's Note: MDPI stays neutral with regard to jurisdictional claims in published maps and institutional affiliations.

(C) 2020 by the authors. Licensee MDPI, Basel, Switzerland. This article is an open access article distributed under the terms and conditions of the Creative Commons Attribution (CC BY) license (http://creativecommons.org/licenses/by/4.0/). 